International Journal of Linguistics, Literature and Culture
Available online at https://sloap.org/journals/index.php/ijllc/
Vol. 7, No. 6, November 2021, pages: 422-440
ISSN: 2455-8028
https://doi.org/10.21744/ijllc.v7n6.1945

\title{
The Multimodal Forms of Tourism Promotional Discourse in the Age of COVID-19
}

Ni Wayan Kasni a I Wayan Budiarta ${ }^{b}$

Article history:

Submitted: 27 August 2021

Revised: 18 September 2021

Accepted: 09 October 2021

\section{Keywords:}

advertising;

hotels;

language use;

multimodal analysis;

visual signs;

\begin{abstract}
The study aimed at finding out the multimodal forms of tourism promotional discourse of promoting hotels in Bali in the age of COVID-19. The theory used in this study is the semiotic theory. In addition, descriptive qualitative is a method used to find forms of advertising, text construction, linguistic aspects, and visual elements of hotel advertisements in the Sanur and Kuta areas in the era of implementing the new normal with researchers as instruments or tools in this study. The data, then, were analyzed inductively. Based on the results of the study, the forms of hotel and tourism advertisements during the implementation of the New Normal were categorized into hotel and tourism audiovisual advertisements and printed hotel and tourism advertisements. Text construction in marketing hotels covers three aspects, namely representational aspects, relational aspects, and textual identity aspects. In addition, the type of semiotic system found in hotel and tourism advertisements during the implementation of the New Normal consists of linguistic aspects, visual forms, and body language. Transcreation of tourism advertisements after the implementation of the new normal consists of verbal, visual, and cultural aspects of advertising.
\end{abstract}

International journal of linguistics, literature and culture () 2021. This is an open access article under the CC BY-NC-ND license (https://creativecommons.org/licenses/by-nc-nd/4.0/).

\section{Corresponding author:}

I Wayan Budiarta,

Universitas Warmadewa, Denpasar, Bali, Indonesia.

Email address: budy4rt476@gmail.com

\footnotetext{
${ }^{a}$ Universitas Warmadewa, Denpasar, Bali, Indonesia

${ }^{\mathrm{b}}$ Universitas Warmadewa, Denpasar, Bali, Indonesia
} 


\section{Introduction}

This Tourism, in line with (Yoeti, 1996), is a travel activity carried out from one place to another for a while which has a recreational purpose. Tourism is inseparable from tourists. Tourists need facilities such as transportation, accommodation, restaurants, entertainment, and other services. The facilities that support tourism activities are then called the tourism industry. The tourism industry is a set of various companies that jointly produce goods and services needed by tourists in particular and travelers in general, during their journey (Sihite, 2000; Yoeti, 1996).

Bali is an area that relies on the tourism sector for its economic growth. As a tourism area, Bali also provides various facilities needed when they visit Bali. The tourism facilities available in Bali absorb quite a lot of labor. However, since the outbreak of the COVID-19 pandemic starting in March 2020, tourism has experienced a slump (Généreux et al., 2021), one of which is in Bali (Anwar, 2020). Many hotel entrepreneurs in Bali have to close. According to data quoted from regional kompas.com as many as 532 tourism companies were closed which had an impact on the workforce. Data obtained from the same source revealed that as many as 42.409 workers were laid off. The data were recorded from the beginning of the COVID-19 pandemic until July 27, 2020. Therefore, the new normal which aims to restore the Indonesian economy during the COVID-19 pandemic is very important to be implemented. According to Yuri, what is meant by new normal is a new order, habit, and behavior based on adaptation to cultivate clean and healthy living behavior (Putsanra, 2020).

The implementation of the new normal opens up opportunities for tourism actors. One of them is the hotel manager, to get back to work. Various ways are done to show that it is safe for tourists to come back to Bali. The strategy taken is to carry out intensive promotions through advertisements (Kristina, 2018), which are equipped with procedures for implementing health protocols in hotels, making other promotional packages that can attract tourists. Each hotel has its strategy and language choice that can boost tourist visits. Preliminary research shows that hotel managers are competing to carry out strategies to revive the hotels they manage with very interesting strategies and the choice of language whose verbal signs are adapted to the COVID-19 pandemic. This is what makes researchers interested in examining the use of language and visual elements of hotel advertisements to revive tourism (Haque, 2015; Amerta et al., 2018).

Many phenomena can be studied about hotel advertisements in the new normal era when viewed from the perspective of advertising and semiotic discourse that is focused on multimodal. Unfortunately, not many have researched it because the term new normal emerged during the outbreak of the COVID-19 pandemic. So far, the research that has been done is general tourism advertisements when tourism is still running normally, such as research on the application of strategies and creative execution in tourism marketing (Sukendro, 2017), information communication technology in tourism promotion activities (Mandjusri \& Irfan, 2019), tourism promotion which advertises online promotion in the tourism industry (Kristina, 2018), the form of video advertisements shown on television and YouTube social media (Muctar \& Kahar, 2019), functional linguistics systems and visual grammar frames (Ansori \& Taopan, 2019), and tourism recovery policies for the city of Bandung as a result of the COVID-19 outbreak (Herdiana, 2020). Therefore, the current research is different from previous studies. However, previous studies can be used as a reference in this study.

Language is a system of signs (De Saussure, 2011). Semiotics is a way of analyzing meanings by looking at the signs. In the sense of semiotics, signs can be in the form of words, pictures, sounds, gestures, and objects (Chandler, 2007; Mjdawi \& Jabi, 2020). These various signs are also called multimodal as it is said (Anstey \& Bull, 2010), a text is said to be multimodal text if the text has two or more semiotic systems. There are five types of semiotic systems, which include: (i) linguistics aspects such as vocabulary, generic structure, and grammar of spoken and written language; (ii) visual aspects such as color, vector, point of view on still and moving objects. (iii) audio aspects such as volume, pitch, and rhythm of music and sound effects; (iv) gesture aspects such as movement, speed, and silence in facial expressions and body language; and (v) location aspects such as the proximity of the object, position of the layout, and setting the distance based on the layout (Salim et al., 2012; Cohen \& Cooper, 1986).

The generic structure of the advertisement consists of visual and linguistic components. These components then consist of a core, display, symbol (verbal), announcement, symbol (nonverbal), and Information on cell phone numbers or places where you can be contacted (Cheong, 2004). Multimodality is a combination of writing, speaking, visualization, sound, music, and many others for communication purposes (Kristina, 2018). The study of multimodal text is one of the studies in semiotics which is defined by Saussure as a study of signs that exist in society (Saussure, 1959). Hereinafter, Chandler (2007), states that semiotics involves a study that not only refers to the study of signs in everyday conversation, but semiotics also studies everything that refers to something else.

Kasni, N. W., \& Budiarta, I. W. (2021). The multimodal forms of tourism promotional discourse in the age COVID19. International Journal of Linguistics, Literature and Culture, 7(6), 422-440. https://doi.org/10.21744/ijllc.v7n6.1945 
This study aims to find (1) forms of hotel advertising during the implementation of the new normal, (2) the construction of texts used to remarket managed hotels, (3) linguistic aspects including vocabulary, generic structure, and grammatical spoken and written language used in hotel advertisements, (4) visual forms used to support the language aspect of hotel advertisements, (5) audio characteristics in advertisements, (6) gesture of the actor's advertisements, and (7) transcreation of tourism advertisements during the implementation of the new normal. The novelty of this research is innovations in hotel advertising to revive tourism. This research is considered very important because the results of this study are expected to be used as a guide in finding innovations in tourism advertisements that involve linguistic aspects combined with visual elements (Chou et al., 2008; Prachanant, 2012).

\section{Materials and Methods}

The research data is qualitative in the form of print and video advertisements. The research was conducted at hotels in Sanur and Kuta because Sanur and Kuta are tourist destinations where in this area many hotels were found which before the COVID-19 outbreak were visited by many tourists. The instruments used in this study were divided into 2 (two), namely the questionnaire instrument and the equipment needed. The equipment needed is a camera, tape recorder, stationery, paper, notebook, computer, and printer. The data is taken from several hotels in Sanur and Kuta areas. Data collection was carried out using the methods of observation, interviews, recordings, photoshoots, and documentation. The observation method was applied at the beginning of the study to obtain initial data about the hotel that was used as the research location. Furthermore, the interview method was carried out to obtain information about the use of language in their advertisements. The shooting method was used to obtain data about print advertisements, while the documentation method was applied to obtain videos about advertisements for the implementation of health protocols in each hotel (Krisjanous, 2016; Wang et al., 2015). The data analysis method consists of several methods, namely observation, content analysis, generic structure vocabulary, visual element analysis, gesture, audio, and advertisement transcreation analysis. In addition, data analysis is carried out with steps that are adapted to the formulation of the problem. The results of the analysis will be presented using formal and informal techniques. Formal techniques are used in presenting data using symbols, pictures about the implementation of the COVID-19 health protocol. Informal techniques are used in presenting the results of the analysis by using sentences.

\section{Results and Discussions}

\subsection{Forms of tourism advertising}

Advertising is one of the means used to promote certain products (Rosa, 2014). The forms of tourism advertisements during the implementation of the New Normal in this study consisted of two forms of tourism advertisements, namely:

\subsubsection{Audio-visual ads}

Audiovisual advertising is one form of advertising that can be seen and heard by consumers simultaneously. This form of advertising, according to Ansori \& Taopan (2019), is more attractive compared to conventional promotional tools such as pamphlets, posters, or brochures. Audio-visual advertisements in this study consisted of two advertisements, namely audio-visual advertisements for the Puri Santrian hotel (http://www.instagram.com/purisantrian/) and audio-visual advertisements for the Prama Sanur Beach Bali hotel (https://www.instagram.com/pramasanurbeach/).

\subsubsection{Print ads}

Print advertising is one form of advertising that is carried out by utilizing print media such as brochures. The following is a tourism print advertisement during the implementation of the new normal which is analyzed in this study. 

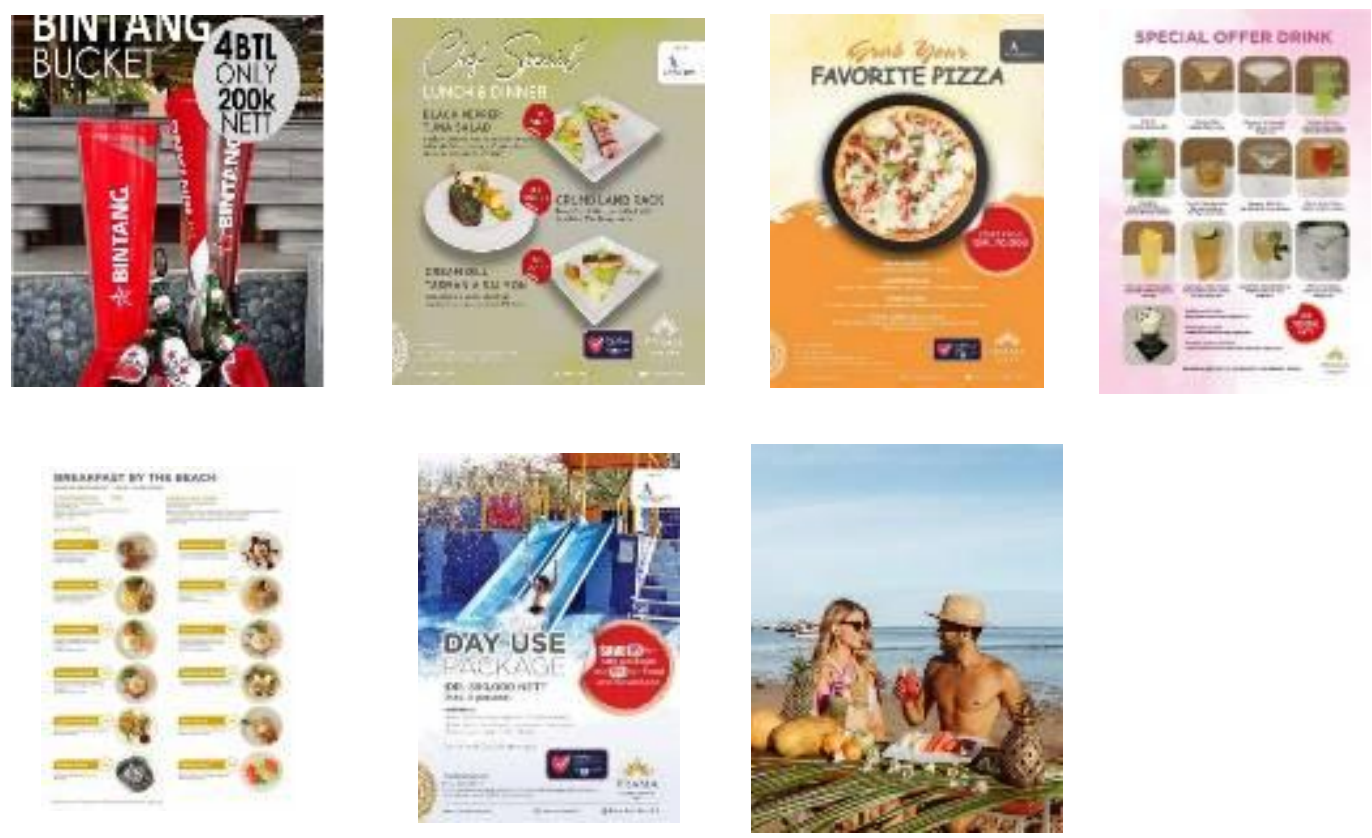

Figure 1. Tourism print advertisements

\subsection{Text construction in hotel marketing}

In marketing, advertising serves to encourage consumer buying interest in a product offered. Thus, the construction of text in advertising plays an important role in marketing products, one of which is hotels. Text construction in marketing products such as hotels includes three aspects, namely the representation aspect, the relational aspect, and other aspects according to Boukari (2020), which is an aspect of textual identity.

\subsection{Linguistic aspects of hotel advertising during the implementation of the new normal}

Advertisements rely on verbal strategies linguistically (Kristina, 2018). The linguistic aspects analyzed in the following audio-visual advertisements are divided into linguistic aspects in spoken language and written language in the advertisements for the Puri Santrian hotel and the Prama Sanur Beach Bali hotel. In line with those categorized by (Tiruneh et al., 2020), these linguistic aspects include vocabulary, generic, and grammatical aspects.

\subsubsection{Linguistic aspects of hotel audio-visual advertisements}

The spoken language in the advertisements for the Puri Santrian and Prama Sanur Beach Bali hotels is an explicit language found in one of the announcement structures. The vocabularies used in both hotel advertisements are vocabularies that are only used during the new normal. This analysis of vocabulary is in line with Mintarsih et al. (2020), one way of analyzing vocabulary is to focus on the alternative wordings. The vocabulary used in the audiovisual advertisement of the Puri Santrian hotel includes the words new norm, social distance, disinfectant, hand sanitizer, temperature check, safe distance, sanitize, mask, face shield, face mask, and safety protocol. Furthermore, the vocabulary used in the audio-visual advertisement of the Prama Sanur Beach Bali hotel includes standard protocol, body temperature, hand wash, hand sanitizer, sterile, disinfectant, physical distancing, clean, healthy, mask, gloves, face shield, pandemic, and new normal. era. Apart from spoken language, there is also written language used in Puri Santrian hotel advertisements. That way, promotions can be more easily understood, in line with what (Rosa, 2014), stated messages in the form of language carried out through spoken and written language makes the audience understand more about what is being promoted.

Kasni, N. W., \& Budiarta, I. W. (2021). The multimodal forms of tourism promotional discourse in the age COVID19. International Journal of Linguistics, Literature and Culture, 7(6), 422-440. https://doi.org/10.21744/ijllc.v7n6.1945 


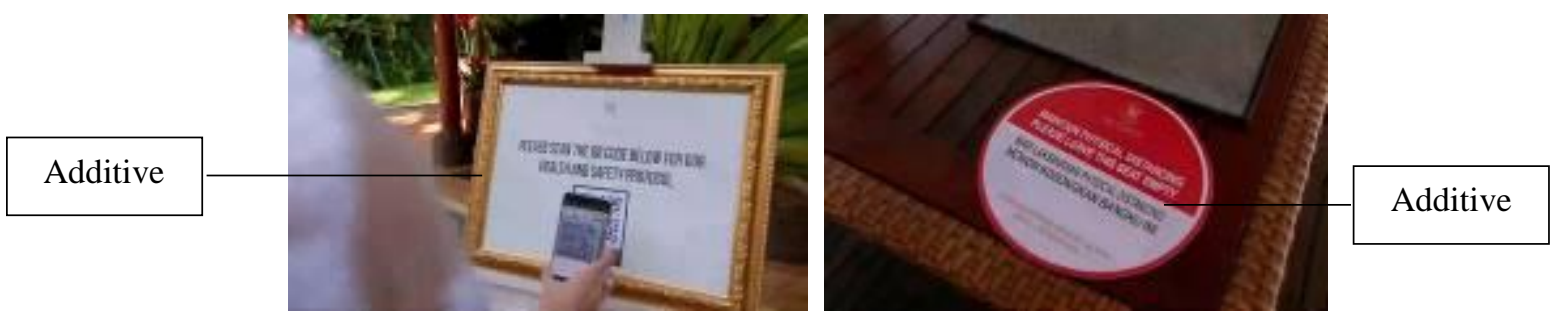

Figure 2. Display of written language on audio-visual advertisements for Puri Santria hotel

The written language is used to explain visual information through verbal texts which are complementary to the advantages possessed by the product.
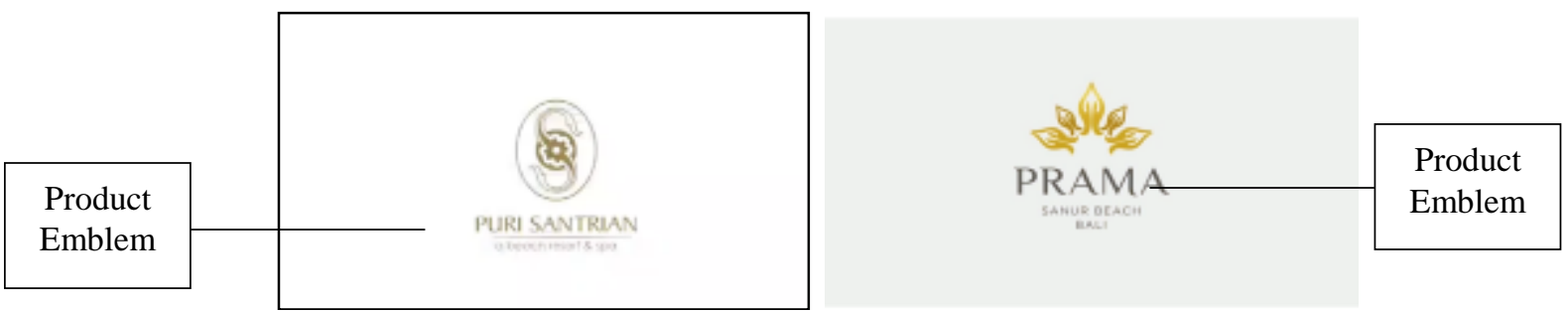

Figure 3. Product emblems on the Prama Sanur Beach Bali hotel audiovisual advertisement

In addition, there is also a product emblem on each audio-visual ad. The product emblem serves to provide identity or status for the product, usually in the form of a product name.

\subsubsection{Linguistic aspects of hotel print advertising}

The linguistic aspect analyzed in this advertisement is focused on the elements of writing. The analyzed aspects include vocabulary, generic structure, and grammatical aspects of written language.

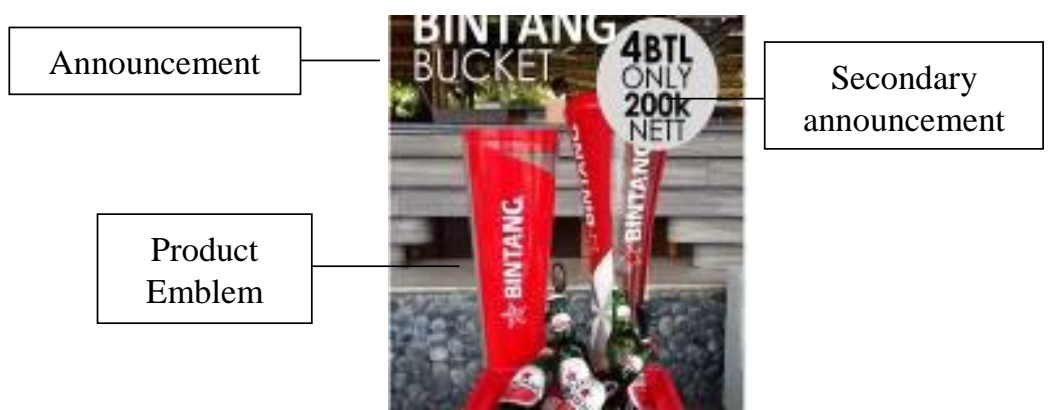

Figure 4. Advertisement of beer Bintang bucket

The ad structure contained in the advertisement, namely announcements, secondary announcements, and product emblems. The 'BUCKET' vocabulary contained in the announcement section above is by the image display that looks like a bucket. The vocabulary of '4 BTL' above is also by the image display, where there are four bottles in the picture. Another vocabulary that was found was the word bottles which was shortened to 'BTL'. In addition, the written language used is declarative (Mak, 2017; Tsaur \& Lin, 2004). 


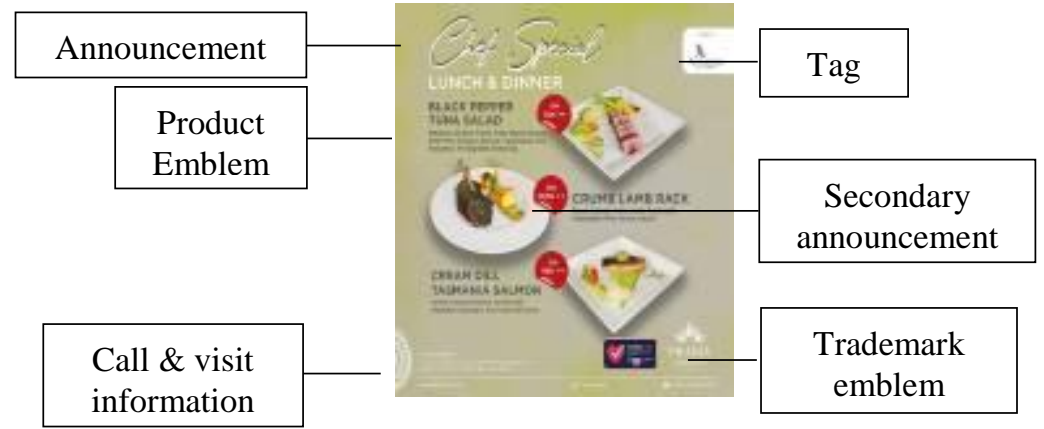

Figure 5. Advertisement of lunch \& dinner

The written language used in this advertisement is found in the announcement structure, secondary announcements, product emblems, trademark emblems, and social media. The writings in the ad above are explicit. The 'Chef Special' vocabulary in the advertisement above is used to inform that the food has a good taste. In addition, the use of capital letters on each food menu informs about the taste and ingredients of the food (Wang et al., 2017; Li et al., 2016). The written languages in the advertisement above are declarative sentences and the language used is informative and clear.

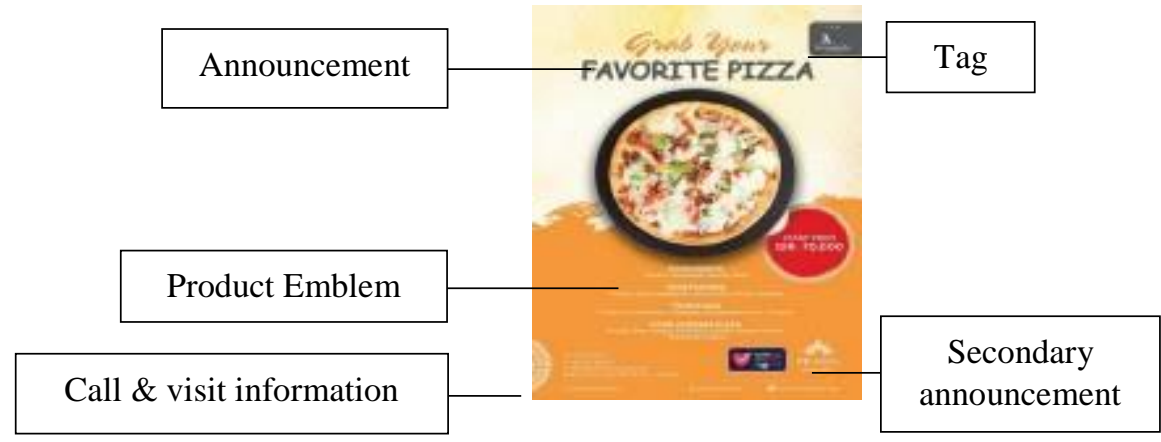

Figure 6. Advertisement of pizza

The written language used in the pizza advertisement above is the written language contained in the announcement structure, secondary announcements, product emblems, trademark emblems, and explicit social media. The interesting vocabulary found in the ad above is FAVORITE PIZZA and IDR. The pizza ad above uses imperative sentences. In addition, the sentences used are informative.

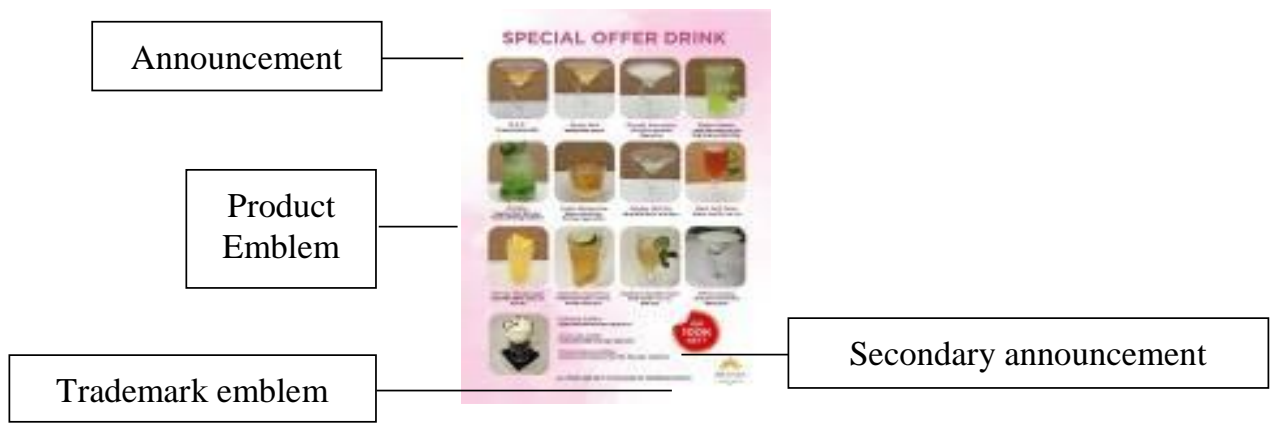

Figure 7. Advertisement of Alcoholic drink

In the advertisement above, the written language used is found in the announcements structure, secondary announcements, product emblems, and the terms and conditions. The use of capital letters in the phrase SPECIAL

Kasni, N. W., \& Budiarta, I. W. (2021). The multimodal forms of tourism promotional discourse in the age COVID19. International Journal of Linguistics, Literature and Culture, 7(6), 422-440. https://doi.org/10.21744/ijllc.v7n6.1945 
OFFER DRINK is useful to emphasize that the ad contains drinks that are on promo. This advertisement is informative. The written language used in the advertisement is a declarative sentence with explicit language.

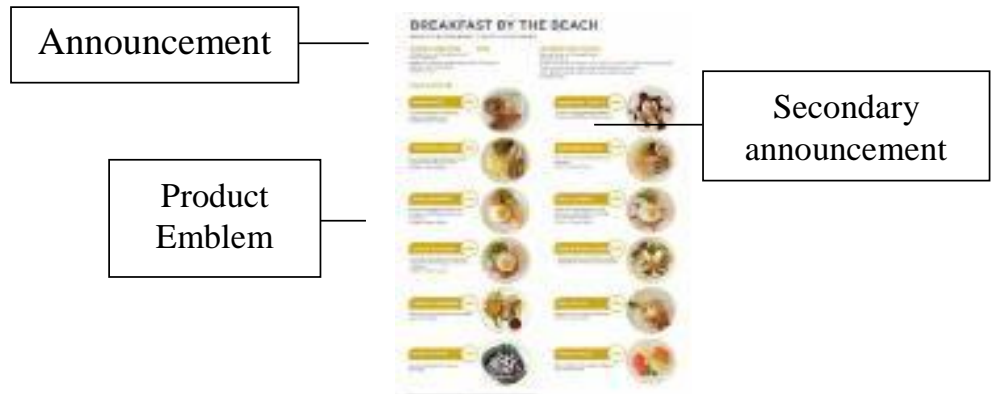

Figure 8. Advertisement of breakfast

The next written language used in the advertisement above is the written language contained in the announcement structure, secondary announcements, product emblems, and terms and conditions. In addition to using English, this advertisement also uses Indonesian vocabulary in several food menus, such as nasi goreng, mie goreng, and so on. The language used in the advertisement above is explicit and informative.

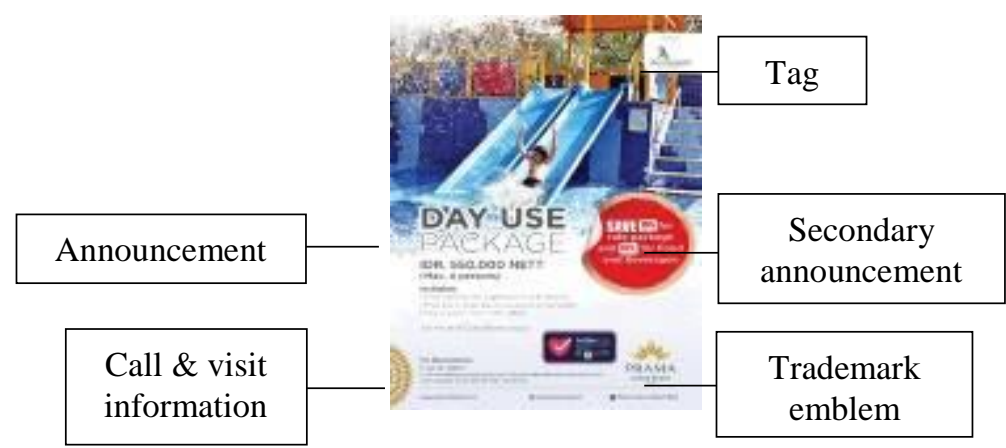

Figure 9. Advertisement of hotel

The phrase 'DAY USE PACKAGE IDR550.000 NETT (Max. 4 people)' is used as a capital sentence to emphasize the advertisement (Magwaro et al., 2018). In addition, the grammatical analysis in this advertisement was found in the use of compound sentences which is in line with the view of (Mintarsih et al., 2020), that grammatical analysis also includes clause grammar. Compound sentences in this ad are the sentences 'SAVE $15 \%$ for rate package and $15 \%$ for Food and Beverage' and 'Free 2 pizzas and 4 glasses of ice lemon tea'.

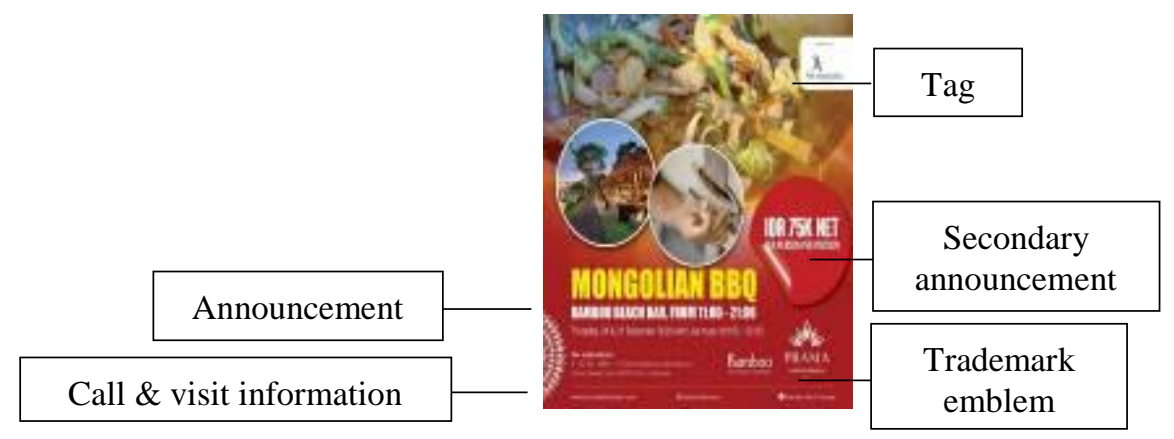

Figure 10. Advertisement of Mongolian BBQ

The written language used in this advertisement is found in the secondary announcement section, product emblems, trademark emblems, and social media. In the phrase, 'MONGOLIAN BBQ' capital letters are used for affirmation in 
advertisements and some capital letters are used in other sentences which serve to indicate the affirmation of the advertising intent.

\subsection{The visual form of hotel ads in the implementation period of new normal \\ 3.4.1 Visual forms in audio-visual advertisements of hotel}

The meaning behind the visual form can be interpreted with many interpretations (Pardesi, 2019). The visual form of an advertisement, as already explained, usually contains aspects such as colors, vectors, points of view on stationary and moving objects. The following visual forms are the visual forms of two hotel audio-visual advertisements, namely the Puri Santrian hotel and the Prama Sanur Beach Bali hotel during the implementation of the new normal. The colors in the audio-visual advertisement at the Puri Santrian hotel below tend to be light in color with very good lighting. Several models play a role in the audio-visual ad. The model who has the main role in the audio-visual advertisement is played by a model who explains verbally about the hotel in the audio-visual advertisement.

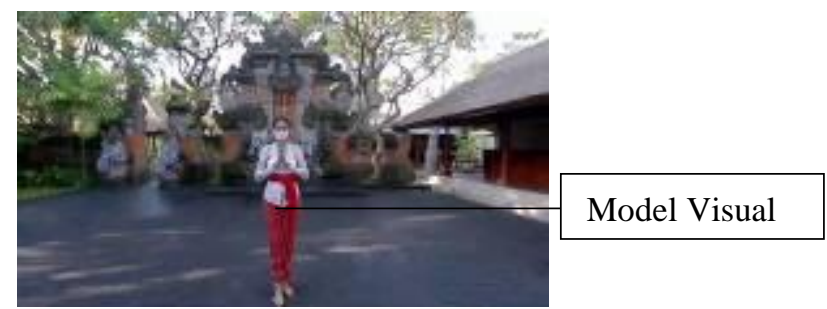

Figure 11. Visual model of audio-visual advertising for Puri Santrian hotel

Furthermore, the colors in the audio-visual advertisement at the Prama Sanur Beach Bali hotel below also use bright colors. There is excellent lighting in the hotel's audio-visual advertisement. In contrast to the Puri Santrian hotel advertisement above, the model in this advertisement does not explain either orally or in writing about the audiovisual advertisement at the Prama Sanur Beach Bali hotel, but rather plays a role in carrying out some directed actions.

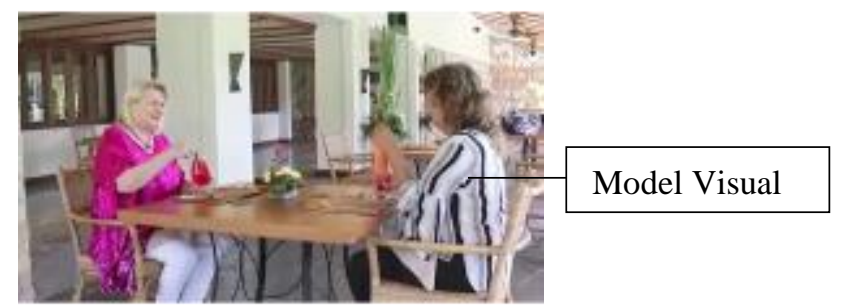

Figure 12. Visual model of audio-visual advertising for Prama Sanur Beach Bali

In addition to color, another visual form that is analyzed is the point of view on the object. As for other points of view besides the object, namely the scenery around the hotel which can be found in the audio-visual advertisements for the Puri Santrian hotel and the Prama Sanur Beach Bali hotel. The following is a point of view on another object of the Puri Santrian hotel, namely the beach around the hotel with a bright blue sky.

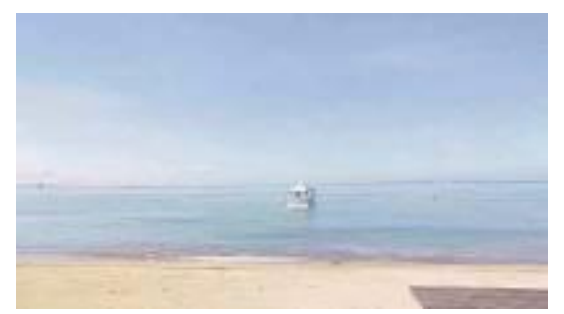

Figure 13. Point of view on other objects in Puri Santrian hotel

Kasni, N. W., \& Budiarta, I. W. (2021). The multimodal forms of tourism promotional discourse in the age COVID19. International Journal of Linguistics, Literature and Culture, 7(6), 422-440. https://doi.org/10.21744/ijllc.v7n6.1945 
At the Prama Sanur Beach Bali hotel, as for other points of view that can be found in audio-visual advertisements, namely the beach and swimming pool located in the hotel or around the hotel. The following is a viewpoint on another object of the Prama Sanur Beach Bali hotel, namely the beachfront filled with beach sand and large trees around the beach, and a large swimming pool.
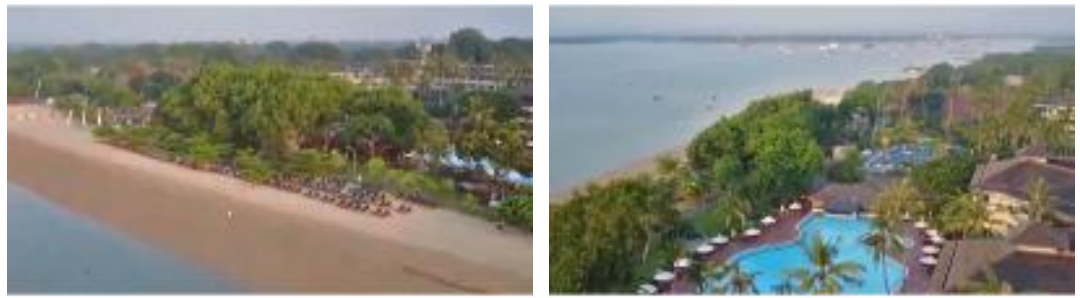

Figure 14. Point of view on other objects at the Prama Sanur Beach Bali hotel

Another visual form contained in this audio-visual advertisement is the visual appearance of the two hotels which consists of the appearance of the outdoors and indoors of the hotel. The visual appearance of the outdoor of the Puri Santrian hotel is as shown in the following picture. The first image is a visual appearance when guests will enter the hotel, while the second image is a visual appearance of the restaurant.
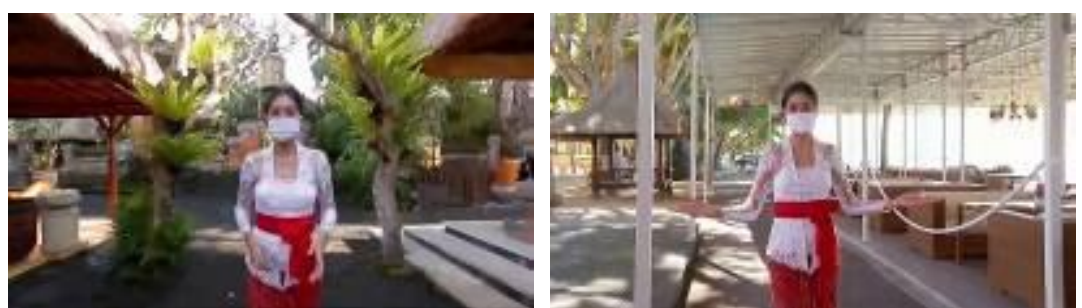

Figure 15. The visual appearance of outdoor the Puri Santrian hotel

The visual appearance in the Puri Santrian hotel room is shown in the following picture. One of the visual appearances in the room at the Puri Santrian hotel is the visual of the hotel room.

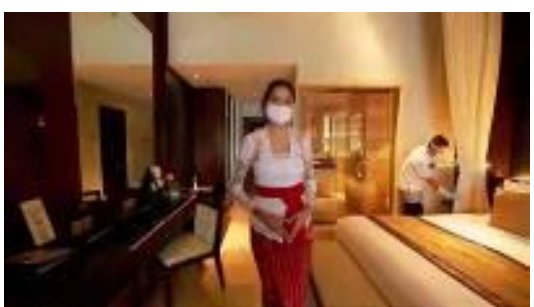

Figure 16. The visual appearance of indoor the Puri Santrian hotel

The visual appearance of the Puri Santrian hotel both indoors and outdoors as in the picture above displays visuals that can attract guests to visit the hotel. So that the audio-visual advertisement at the Puri Santrian hotel can be said to have a good visual appearance to be used during the implementation of the new normal.

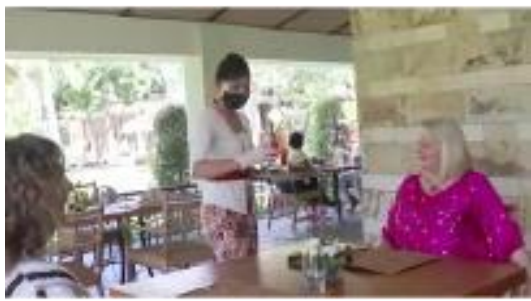

Figure 17. Visual appearance of outdoor the Prama Sanur Beach Bali hotel 
The visual appearance in the picture above shows the visual of outdoor the Prama Sanur Beach Bali hotel. One of the visual appearances of the outdoor is the visual appearance of the restaurant.

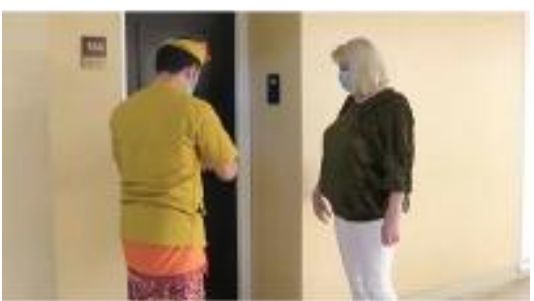

Figure 18. Visual appearance of indoor the Prama Sanur Beach Bali hotel

While the appearance in the room at the Prama Sanur Beach Bali hotel can be seen in the picture above. The visual appearance is located in front of the Prama Sanur Beach Bali hotel room. Based on the visual appearance of the indoor and outdoor of the Prama Sanur Beach Bali hotel in the audio-visual advertisement above, it can be seen that the advertisement has good visuals that can attract guests to visit the hotel.
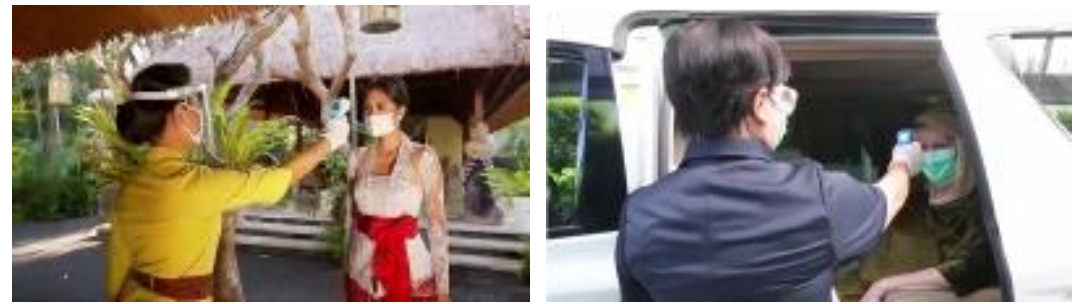

Figure 19. Differences in the visual form of the Puri Santrian hotel and Prama Sanur Beach Bali hotels (1)

Another visual difference seen in the ad is when checking body temperature as shown in the image above. In the Puri Santrian hotel advertisement, it appears that body temperature checks are carried out when guests enter the hotel lobby. While in the Prama Sanur Beach Bali hotel advertisement, it appears that body temperature checks are carried out when guests are about to get out of the vehicle.
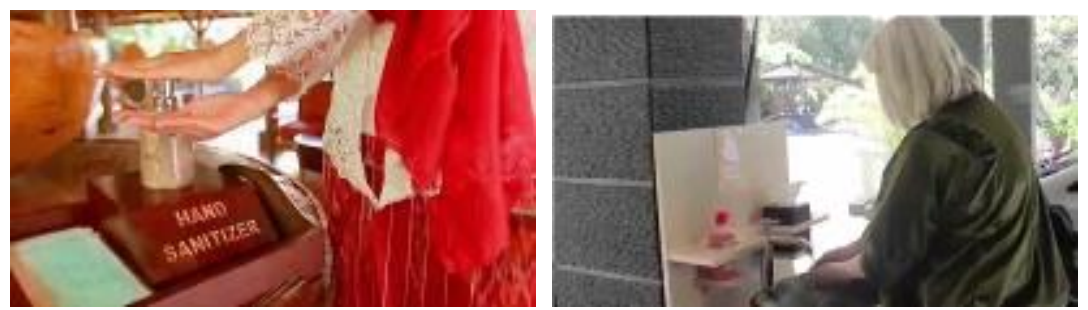

Figure 20. Differences in the visual form of the Puri Santrian hotel and Prama Sanur Beach Bali hotels (2)

The next visual difference between the two hotels is shown in the figure above. At the Puri Santrian hotel, guests are asked to use hand sanitizer before entering the hotel. Meanwhile, at the Prama Sanur Beach Bali hotel, guests are asked to wash their hands before entering the hotel. Another difference is that at the Puri Santrian hotel, the color used to show the distance sign is a bright color or red in the round image with the image of the sole contained in the round red image which serves to keep guests at a distance from other guests or hotel staff. standing on the picture.

Kasni, N. W., \& Budiarta, I. W. (2021). The multimodal forms of tourism promotional discourse in the age COVID19. International Journal of Linguistics, Literature and Culture, 7(6), 422-440. https://doi.org/10.21744/ijllc.v7n6.1945 

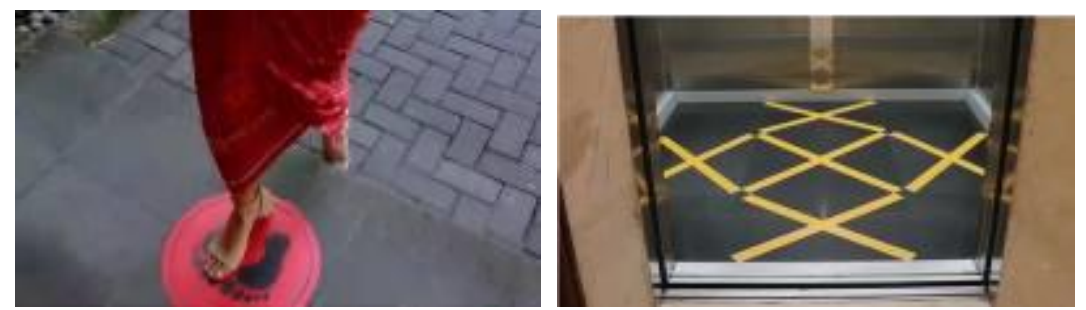

Figure 21. Visual signs of social distancing at (a) Puri Santrian hotel, (b) Prama Sanur Beach Bali

At the Prama Sanur Beach Bali hotel, the color used to show the distance sign is a dark color with a yellow cross in the shape of a cross which has the same function as the distance guard sign at the Puri Santrian hotel, which functions to keep guests at a distance from other guests or hotel staff by not stand on the yellow cross.

\subsubsection{The visual form of hotel print ads during the new normal implementation}

The following advertisements have a visual form that can attract the attention of consumers during the implementation of the new normal. The visual form of an advertisement generally contains aspects such as color, vector, point of view on stationary and moving objects.

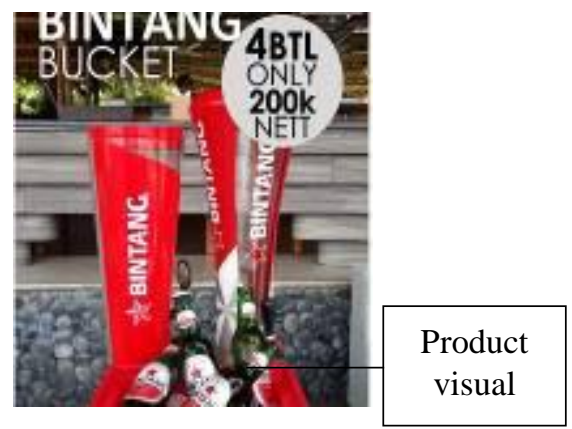

Figure 22. Visual of beer Bintang bucket advertisement

The beer bucket ad above has clear visuals and matches the writing on the ad. There is a match between the words 'BINTANG BUCKET' and the image of the bucket in the ad. In addition, in the advertisement, four bottles of star beer match the writing on the ad, namely '4 BTL ONLY 200k NETT'. The interesting part of the ad above, namely the discounted price of Bintang Bucket beer. The image in the advertisement contains an explicit meaning.

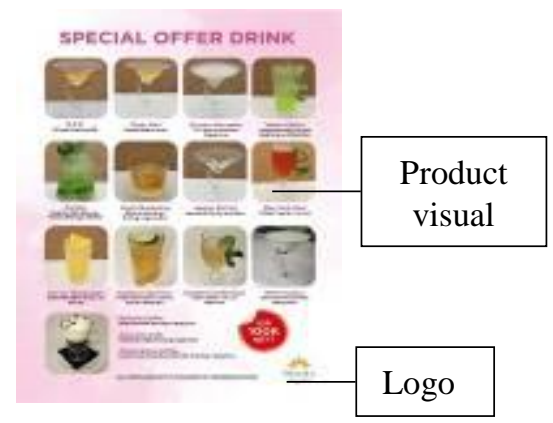

Figure 23. Visual of alcoholic drink advertisement

Each image in the alcoholic beverage advertisement above is given information about the composition contained in the drink. The advertisement display is also equipped with the logo of the hotel that provides drinks with special offers. The most important part contained in the ad, namely the discount on the drink in the image. In addition, the choice of unobtrusive colors, such as pink and white, makes the image of the drink in the ad above look real. 


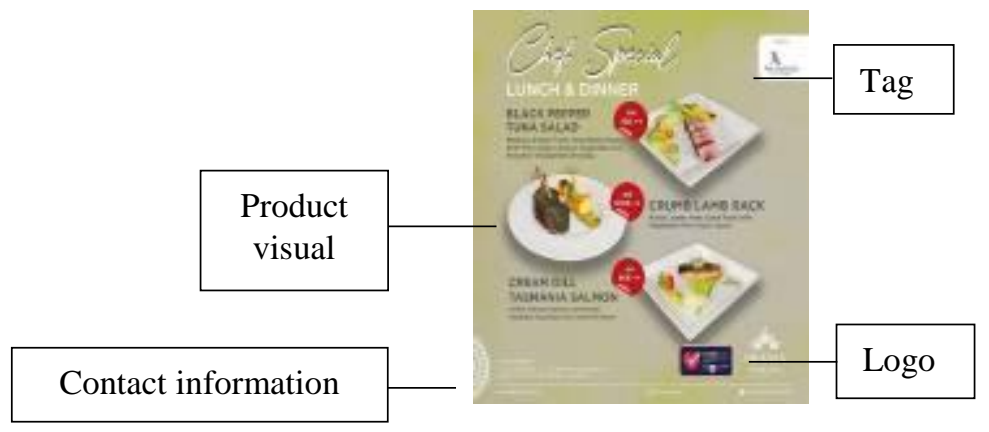

Figure 24. Visual of lunch and dinner advertisement

The product visuals in the ad above look very real and match the existing composition. In the ad, there is a composition of each food. Furthermore, there are two logos in the food advertisement above to convince consumers of the product. The colors selected and used in the advertising background above do not stand out from the food colors. In addition, there is also contact information and hotel/restaurant addresses in the ad above that consumers can use for reservations. The part that is very interesting and highlighted in the ad above, is the different discounts on each food.

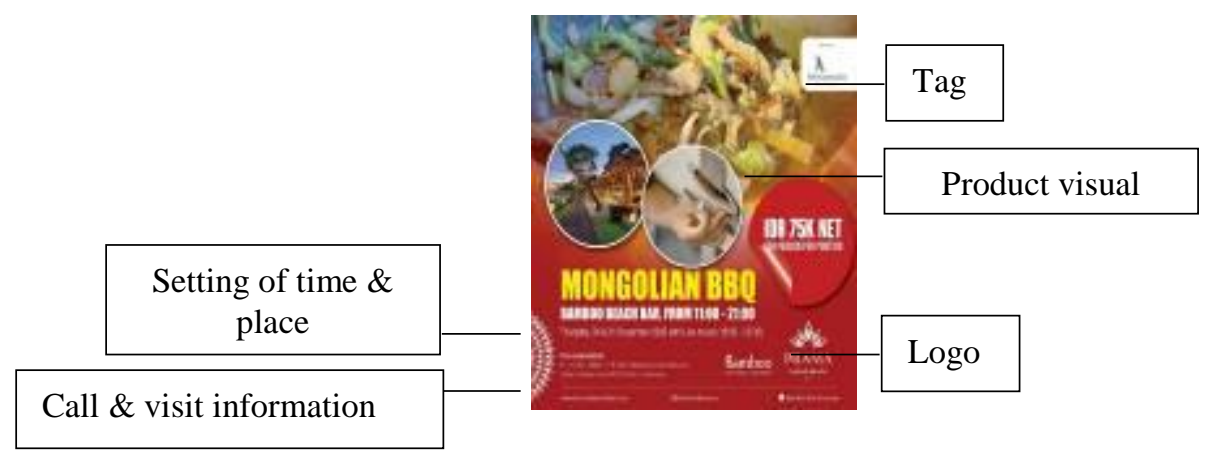

Figure 25. Visual of Mongolian BBQ advertisement

Product visuals, logos, time, and place settings make the advertisement above an informative advertisement. In this advertisement, there are three product logos. The ad is composed of several colors, such as yellow on the words MONGOLIAN BBQ, white on discounted prices, timing, place, additional information, logos and social media, and maroon which is the background color for the ad.

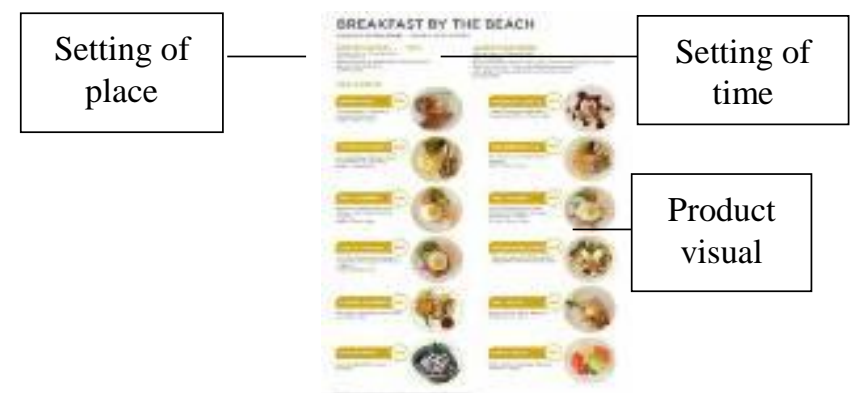

Figure 26. Visual of breakfast advertisement

In the ad above, there are product visuals, time, and place settings. The product visual displays pictures of the food, the name of the food, and the composition of the food. As can be seen in the ad above, BASILICO RESTAURANT

Kasni, N. W., \& Budiarta, I. W. (2021). The multimodal forms of tourism promotional discourse in the age COVID19. International Journal of Linguistics, Literature and Culture, 7(6), 422-440. https://doi.org/10.21744/ijllc.v7n6.1945 
is information about the place in the ad. Just like other ads, this ad also provides discounts. This ad has a white background that supports the color of the food image in the ad.

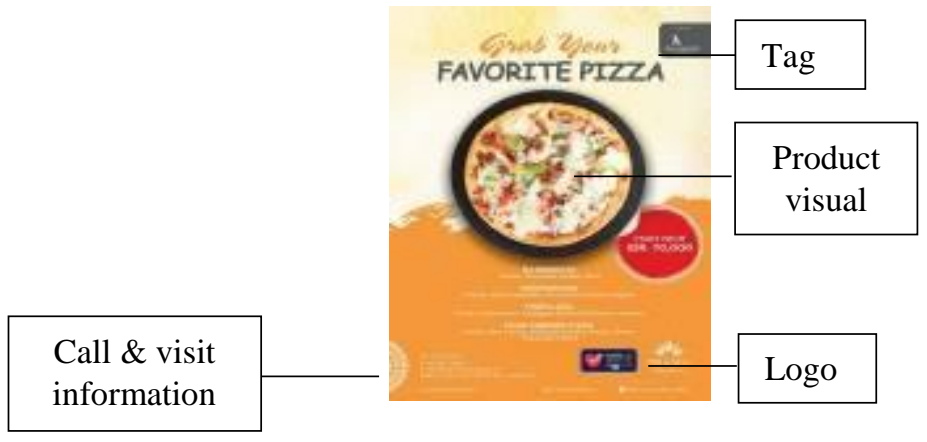

Figure 27. Visual of pizza advertisement

In this advertisement, there are two logos from restaurants to convince consumers of the product. In addition, in the advertisement, there is also contact information that consumers can contact for reservations and social media for consumers to explore regarding the products offered.

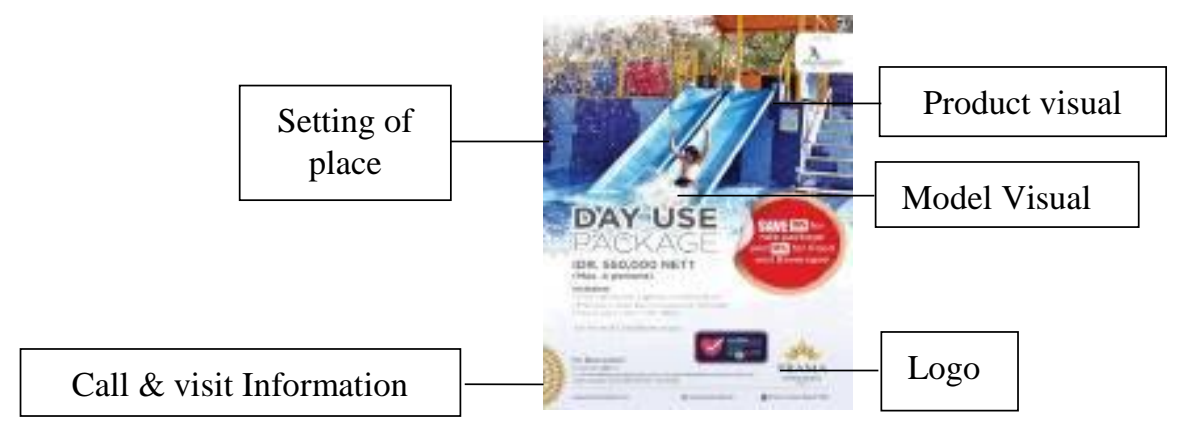

Figure 28. Visual of Prama Sanur Beach Hotel advertisement

In the advertisement above there is a visual model, that is a child who is playing in the swimming pool. In addition, there is a visual display of the product, namely the swimming pool. Some other product visuals are not shown in this ad such as 2 pizzas and 4 glasses of iced lemon tea, towels, and hotel rooms. Overall, the colors in this ad are very integrated and support each other with other colors.

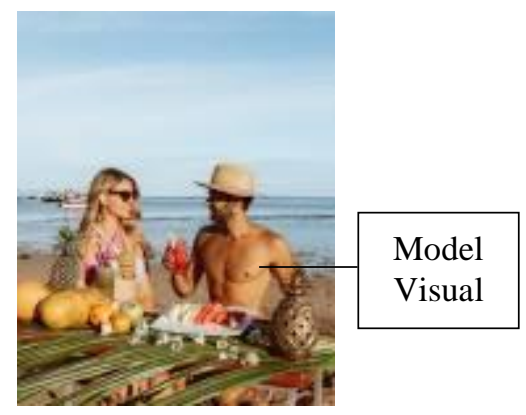

Figure 29. Visual of Puri Santrian Hotel advertisement

Hotel packages offered at Puri Santrian consist of room, breakfast, food, and drinks. From the picture above, it can be seen that there is a visual model in the display of the ad. The two models in the advertisement show activities being carried out on the beach, namely drinking juice. 


\subsection{Audio characteristics of hotel ads during the implementation of new normal}

Audio characteristics in an advertisement usually contain aspects such as volume, high and low tone, and rhythm of music and sound effects. In the Puri Santrian hotel advertisement, there is music as the background audio of the model speaking in the ad. The audio in the Puri Santrian hotel advertisement has a large volume compared to the audio volume in the Prama Sanur Beach Bali hotel advertisement. In addition, the volume of the music contained in the ad is lower or not dominant than the speaker's audio. The type of music used in the ad simply sounds like uplifting music.

In the Prama Sanur Beach Bali hotel advertisement, there is also music as the background audio of the speaker in the advertisement. The audio in the Prama Sanur Beach Bali advertisement has a smaller volume than the audio volume in the Puri Santrian hotel advertisement. The music volume in the Prama Sanur Beach Bali advertisement is almost as high as the speaker audio volume in the advertisement.

\subsection{The body language of the cast of hotel ads during the implementation of the new normal 3.6.1 Body language/gesture of the cast of hotel audio-visual ads}

Body language is a multimodality semiotic system. Body language in an advertisement contains aspects such as movement, speed, and silence in facial expressions and body language.
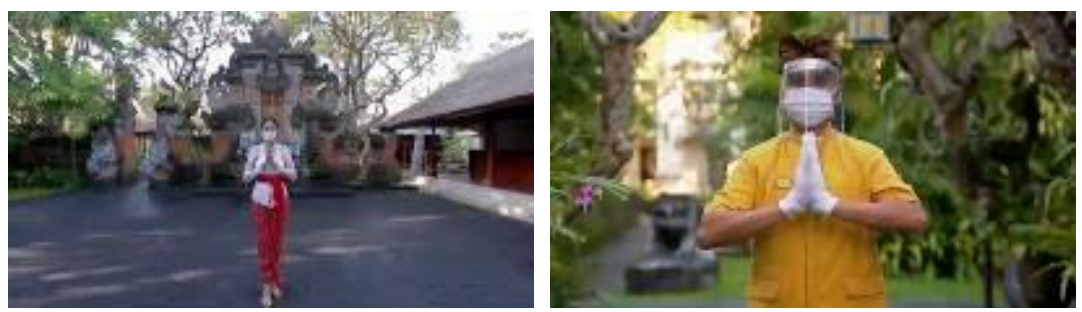

Figure 30. Body language in the form of greetings at the Puri Santrian hotel

The body language of the models above at the Puri Santrian hotel shows greetings to hotel guests. Greetings can also be shown as in the picture above with an upright body position. In addition to shaking hands, greetings can also occur as in the picture above, especially with the pandemic situation.
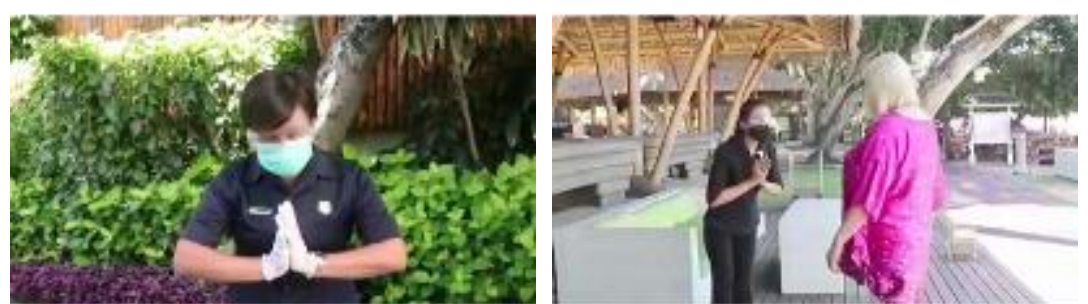

Figure 31. Body language in the form of greetings at the Prama Sanur Beach Bali hotel

The body language of the models above at the Prama Sanur Beach Bali hotel shows the same language, namely greetings to guests. However, the body language in the picture above is different from the previous body language where the hotel staff is seen bowing while greeting guests. Body language like this serves to show respect to guests and a sense of service.

Kasni, N. W., \& Budiarta, I. W. (2021). The multimodal forms of tourism promotional discourse in the age COVID19. International Journal of Linguistics, Literature and Culture, 7(6), 422-440. https://doi.org/10.21744/ijllc.v7n6.1945 


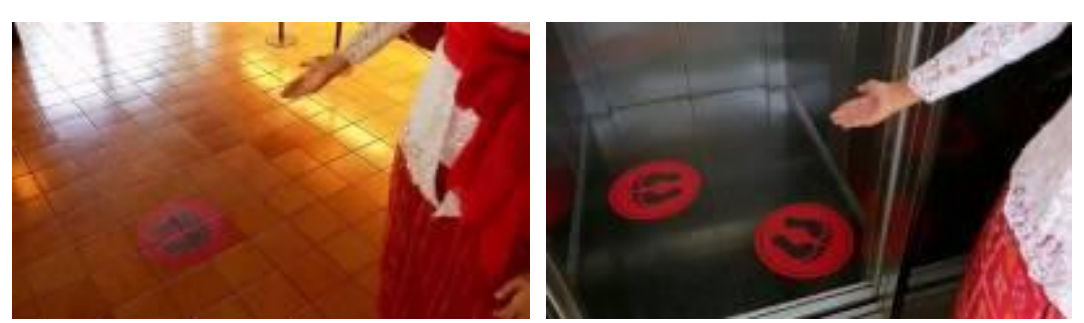

Figure 32. Body language pointing to a social distancing sign by Puri Santrian hotel staff

Based on the picture above, it can be seen that the body language of the Puri Santrian hotel staff is in the form of a gesture pointing to the distance sign on the hotel floor. Meanwhile, the same body language is also used by the Prama Sanur beach hotel staff in the picture below but is designated differently.
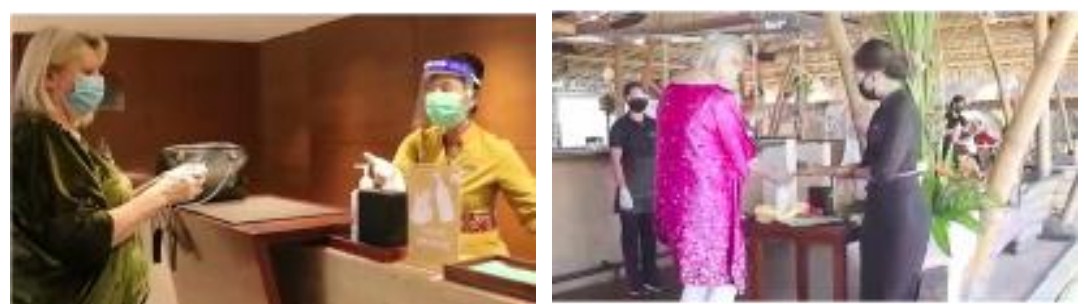

Figure 33. Body language pointing to hand sanitizer by staff Prama Sanur Beach Bali hotel

In the picture above, the Prama Sanur Beach Bali hotel staff points to the hand sanitizer that has been provided on the table. The pointing gesture has the meaning of inviting guests to use hand sanitizer.
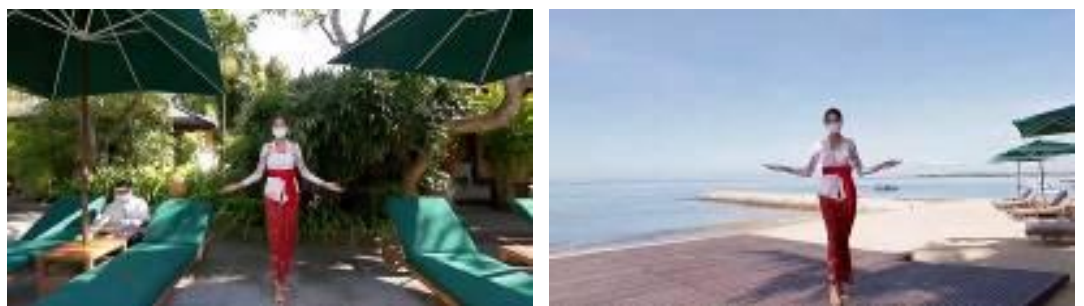

Figure 34. Body language showing the environment

The body language where both the right and left hands of the hotel staff are stretched wide enough to the right for the right hand and to the left for the left hand as in the picture above means that the staff is explaining about the surrounding environment.

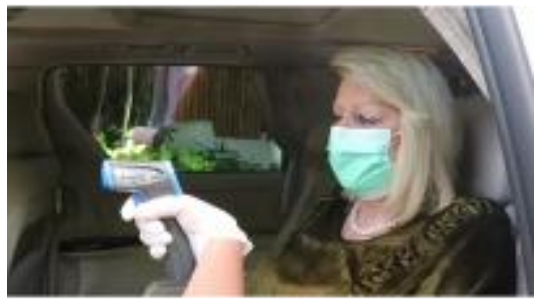

Figure 35. Body language (nodding)

In the audio-visual advertisement of the Prama Sanur Beach hotel above, there is a model from the hotel advertisement who is checking body temperature. In the advertisement, it is clear that the model or guest nods his head when the hotel staff shows the results of his body temperature check. The body expression in the form of nodding as done by the model means that the model understands, understands, and agrees with the body temperature. 

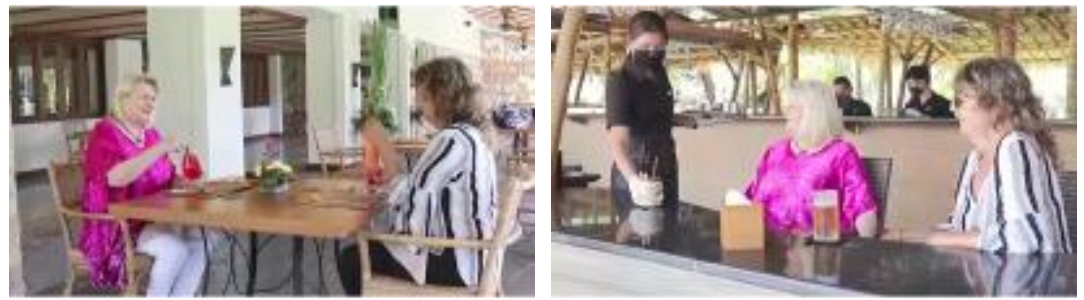

Figure 36. Body language (smiling)

The body language of the model or guest above is in the audio-visual advertisement of the Prama Sanur Beach Bali hotel. It is seen in the two pictures that the model or guest is smiling. Facial expressions such as smiling seen in the picture have a meaning where the guest feels happy.

\subsubsection{Body language/gesture of the cast of hotel print ads}

Body language, as previously explained, in advertisements usually consists of aspects such as movement, speed, and silence in facial expressions and body language.

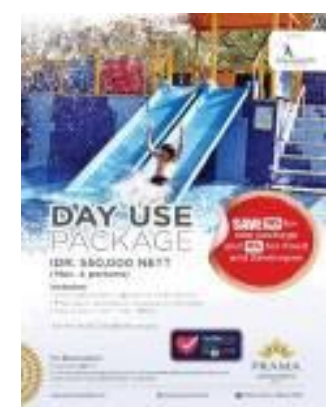

Figure 37. Body language in hotel advertisements

In the picture above, there is an actor in the ad. The ad is played by a boy who is in the water playground. There are various toys on the water playground, such as slides, artificial houses, and various other games. The cast showed their happy body language by raising both hands while sliding, looking at happy faces, and laughing at the boy.

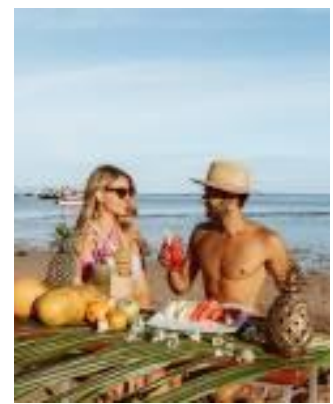

Figure 38. Body language in hotel advertisement of the Puri Santrian

In the picture above, there are two actors in the ad, namely a man and a woman who are on the beach. The body language seen in the picture is happiness which is indicated by a smile. It was also seen that they raised their respective glasses indicating that they were drinking.

Kasni, N. W., \& Budiarta, I. W. (2021). The multimodal forms of tourism promotional discourse in the age COVID19. International Journal of Linguistics, Literature and Culture, 7(6), 422-440. https://doi.org/10.21744/ijllc.v7n6.1945 


\subsection{Transcreation of hotel advertisement after the implementation of the new normal \\ 3.7.1 Transcreation of hotel audio-visual ads after the implementation of the new normal}

Transcreation is the process of adapting the text (usually according to its function) to adapt the language and culture to the target (Humphrey, 2011). The pattern of transcreation analysis consists of verbal, visual, and cultural aspects of advertising (Pedersen, 2014). Verbal aspects of audio-visual advertisements in this study consisted of written language and spoken language, but spoken language was more likely to be used. The spoken language is contained in the announcement structure, secondary announcements, linguistic emblems, and salience. While the visual aspects of the two hotel advertisements contain the appearance of the hotel, both the visual appearance of indoor and outdoor of the hotel. Each audio-visual advertisement, both the Puri Santrian hotel and the Prama Sanur Beach Bali hotel, received bright lighting. The cultural aspects seen in the audio-visual advertisements for the Puri Santrian hotel and the Prama Sanur Beach Bali hotel are foreign culture and Indonesian culture, especially the culture found on the island of Bali.

\subsubsection{Transcreation of hotel print ads after the implementation of the new normal}

The written language contained in these advertisements is contained in the announcement structure, secondary announcements, calls and visits, product emblems, trademark emblems, tags, place settings, and time settings. The visual aspect of the tourism advertisements above shows an explicit meaning. The use of colors that are not too flashy is very interesting to look at. Some affirmations in advertisements are indicated by using capital letters. The visuals of each product, both food, and beverage as well as other products, are displayed very clearly. The cast in print advertisements is foreigners. Meanwhile, the cultural aspect of the tourism advertisements above shows clearly that the culture that is highlighted is foreign culture and customs where it can be seen from the clothes of the actors. In addition, the types of food and drinks show foreign flavors. Indonesian culture is shown very little, that is in the type of food.

\section{Conclusion}

The conclusions obtained based on the formulations of the problem in this study, namely the forms of hotel advertising during the implementation of the new normal were categorized into audio-visual advertisements and print advertisements, text construction in marketing hotels covers three aspects, namely representational aspects, relational aspects, and aspects of textual identity, the linguistic aspects found in the advertisements in this study include aspects of vocabulary, generic structure, and grammatical written and spoken language, the visual form of hotel advertisements can be seen in the tag display, product visuals, visual models, logos, and information contact, setting of place, setting of time, call and visit information, audio characteristics of hotel audio-visual advertisements include low and high volume, body language shown in hotel advertisements shows the meaning of excitement, pleasure, happiness, and confidence, and advertisement transcreation tourism after the implementation of the new normal consists of verbal, visual, and cultural aspects from advertising.

\section{Conflict of interest statement}

The authors declared that's they have no competing interests.

\section{Statement of authorship}

The authors have a responsibility for the conception and design of the study. The authors have approved the final article.

\section{Acknowledgments}

We are grateful to two anonymous reviewers for their valuable comments on the earlier version of this paper. 


\section{References}

Amerta, I. M. S., Sara, I. M., \& Bagiada, K. (2018). Sustainable tourism development. International research journal of management, IT and social sciences, 5(2), 248-254.

Ansori, M., \& Taopan, L. L. (2019). A multimodal discourse of promotional video Wonderful Indonesia. English and Literature Journal, 6(1), 1-18.

Anstey, M., \& Bull, G. (2010). Helping teachers to explore multimodal texts. Curriculum and Leadership Journal, 8(16).

Anwar, M. C. (2020). Menyerah, Pengusaha Hotel di Bali Bertumbangan. Retrieved September 30, 2021

Boukari, N. (2020). Seasonal Jobs, Employment Insurance and the Labor Supply of Couples: An Empirical Economic Analysis Applied to the 2012 Reform.

Chandler, D. (2007). Semiotics: the basics. Routledge.

Cheong, Y. Y. (2004). Open linguistics series: The construal of ideational meaning in print advertisements (Edited by Kal L. O'Halloran). Continuum, London and New York, 165-174.

Chou, T. Y., Hsu, C. L., \& Chen, M. C. (2008). A fuzzy multi-criteria decision model for international tourist hotels location selection. International journal of hospitality management,27(2), 293-301. https://doi.org/10.1016/j.ijhm.2007.07.029

Cohen, E., \& Cooper, R. L. (1986). Language and tourism. Annals of tourism research, 13(4), 533-563. https://doi.org/10.1016/0160-7383(86)90002-2

De Saussure, F. (2011). Course in general linguistics. Columbia University Press.

Généreux, M., David, M. D., O’Sullivan, T., Carignan, M. È., Blouin-Genest, G., Champagne-Poirier, O., ... \& Roy, M. (2021). Communication strategies and media discourses in the age of COVID-19: an urgent need for action. Health Promotion International, 36(4), 1178-1185.

Haque, Z. (2015). The impact of economic crisis on tourism industry. International Research Journal of Engineering, IT and Scientific Research, 1(1), 12-23.

Herdiana, D. (2020). Rekomendasi kebijakan pemulihan pariwisata pasca wabah Corona Virus Disease 2019 (COVID-19) di Kota Bandung. Jurnal Master Pariwisata (JUMPA), 7(1), 1-30.

Humphrey, L. (2011). The little book of Transcreation. Mother Tongue.

Krisjanous, J. (2016). An exploratory multimodal discourse analysis of dark tourism websites: Communicating issues around contested sites. Journal of Destination Marketing \& Management, 5(4), 341-350. https://doi.org/10.1016/j.jdmm.2016.07.005

Kristina, D. (2018, August). Multimodal Branding of Indonesian Online Promotional Discourse in Hospitality Industries. In 4th PRASASTI International Conference on Recent Linguistics Research (PRASASTI 2018). Advances in Social Science, Education and Humanities Research (Vol. 166).

Li, Q., Huang, Z. J., \& Christianson, K. (2016). Visual attention toward tourism photographs with text: An eyetracking study. Tourism Management, 54, 243-258. https://doi.org/10.1016/j.tourman.2015.11.017

Magworo, G. R., Odhiambo, E., \& Owala, S. (2018). An analysis of the linguistic features used in selected social interactions on Facebook. Education and Linguistics Research, 4(1), 35-44.

Mak, A. H. (2017). Online destination image: Comparing national tourism organisation's and tourists' perspectives. Tourism Management, 60, 280-297. https://doi.org/10.1016/j.tourman.2016.12.012

Mandjusri, A., \& Irfan, E. (2019). Pemahaman Praktis Strategi Influencer Promosi Pariwisata. Journal of Tourism and Creativity, 2(1).

Mintarsih, S. S., Kodrat, D., \& Emiliasari, R. N. (2020). Tempo's perspective on the representation of government in dealing with covid-19 cases. CALL, 2(2).

Mjdawi, A. M. A.-, \& Jabi, S. I. (2020). A Pragma-Semiotic Analysis of Emoticons in Social Media. Macrothink Institute: Education and Linguistics, 6(2).

Muchtar, A., \& Kahar, K. (2019). Iklan Pariwisata Kota" Visit Makassar 2016"(Karya Komunikasi). KAREBA: Jurnal Ilmu Komunikasi, 8(1), 9-22.

Pardesi, H. Y. (2019). Power Relation Reproduction Through Images: A Critical Semiotic Analysis of Language Textbooks. Education and Linguistics Research, 5(1).

Pedersen, D. (2014). Exploring the concept of transcreation: Transcreation as 'more than translation'?. Cultus: The Journal of intercultural mediation and communication, 7, 57-71.

Prachanant, N. (2012). Needs analysis on English language use in tourism industry. Procedia-Social and Behavioral Sciences, 66, 117-125. https://doi.org/10.1016/j.sbspro.2012.11.253

Kasni, N. W., \& Budiarta, I. W. (2021). The multimodal forms of tourism promotional discourse in the age COVID19. International Journal of Linguistics, Literature and Culture, 7(6), 422-440. https://doi.org/10.21744/ijllc.v7n6.1945 
Putsanra, D. V. (2020). Arti New Normal Indonesia: Tatanan Baru Beradaptasi dengan COVID-19. Tirto. id.

Rosa, R. N. (2014). Analisis multimodal pada iklan Sunsilk Nutrien Sampo Ginseng. Kajian Linguistik, 12(2), 136148.

Salim, M. A. B., Ibrahim, N. A. B., \& Hassan, H. (2012). Language for tourism: A review of literature. ProcediaSocial and Behavioral Sciences, 66, 136-143. https://doi.org/10.1016/j.sbspro.2012.11.255

Saussure, F. D. (1959). Course in General Linguistics. Ed. Charles Bally, Albert Sechehaye, and Albert Riedlinger. Trans. Wade Baskin. New York: Philosophical Library, 350-358.

Sihite, R. (2000). Tourism Industry. Surabaya: SIC.

Sukendro, G. G. (2017, October). Kreativitas Indonesia: Analisis Iklan Pariwisata Indonesia "Pesona Indonesia". In Prosiding Seminar dan Call For Paper (Vol. 20, p. 21).

Tiruneh, D., Baye, G., \& Dubi, Y. B. (2020). A Critical Discourse Analysis of COVID-19 in Ethiopia: Rethinking the Past and Defining the Present. Journal of Language and Literature, 20(2), 318.

Tsaur, S. H., \& Lin, Y. C. (2004). Promoting service quality in tourist hotels: the role of HRM practices and service behavior. Tourism management, 25(4), 471-481. https://doi.org/10.1016/S0261-5177(03)00117-1

Wang, B., Shao, C., \& Ji, X. (2017). Dynamic analysis of holiday travel behaviour with integrated multimodal travel information usage: A life-oriented approach. Transportation Research Part A: Policy and Practice, 104, 255280. https://doi.org/10.1016/j.tra.2017.03.013

Wang, B., Shao, C., Li, J., Weng, J., \& Ji, X. (2015). Holiday travel behavior analysis and empirical study under integrated multimodal travel information service. Transport Policy, 39, 21-36. https://doi.org/10.1016/j.tranpol.2014.12.005

Yoeti, O. A. (1996). Pengantar Ilmu Pariwisata, Bandung: Angkasa. 